\author{
Kseniia Pashaieva ${ }^{1}$
}

\title{
AZERBAIJAN AND THE SECURITY COMPLEX OF THE SOUTH CAUCASUS
}

Keywords: Energy, geopolitics, Russia, Nagorno-Karabakh, conflict, the EU, the USA, Iran, Turkey.

\begin{abstract}
This article reviews the academic literature on the regional security complex of the South Caucasus, which has been drawing the attention of the academic community for a long time. The paper aims to examine the security dynamics in the South Caucasus with a focus on Azerbaijan and a way in which domestic security is interconnected and linked to the region's neighborhood and global arena. The conceptual framework for the paper is the regional security complex theory, elaborated by Barry Buzan and Ole Wæver. South Caucasus is an unstable region with several secessionist conflicts and interstate wars, exposed to the influence of its neighbors, which shape the regional security environment. Besides, the region is riven by geopolitical fractures as regional states have various foreign policy orientations, which hampers the resolution of regional conflicts and complicates cooperation. The research is carried at three levels of analysis - the domestic level, reviewing internal vulnerabilities and state to state relations, interregional level, examining dynamics between regional and neighboring states, and the last level - global, considering the interplay between regional and the world-leading powers. Correspondingly, sections of the paper study internal challenges and threats of the regional states, examine relations between Azerbaijan, Armenia, Georgia, and their neighborhood - Turkey, Iran, Russia, as well as global powers - the EU and the US to analyze similar and conflicting interests and patterns of influence. The article concludes that the South Caucasus security environment is unstable, hampered by the failure of democratic transformation and unresolved conflicts, namely Nagorno-Karabakh, which Russia uses as a tool to keep Caucasian states in a sphere of its influence. It is evident that Azerbaijan plays a vital role in the production and transit of hydrocarbons from the Caspian region to Europe. Therefore, it is crucial to eliminate threats coming from the region and to ensure the security of energy infrastructure, carrying energy resources westwards.
\end{abstract}

1 Postgraduate Student at the Department of International Relationships, Odessa I. I. Mechnikov National University, kseniya.p.2014@gmail.com. ORCID ID: 0000-00022576-6403. 


\section{INTRODUCTION}

Azerbaijan, Armenia and Georgia are a single region - the South Caucasus, situated at the crossroads of Asia and Europe. Despite the fact, that states of the South Caucasus have little in common as there is no inclusive economic and security cooperation, regional integration framework, common culture, language, and religion. The key factor constituting the region is the interconnectedness of security risks and threats. Azerbaijan, Georgia and Armenia suffer from weak system of state institutions, fragile rule-oflaw, ungoverned territories, territorial and ethnic conflicts, and foreign influence, etc. Moreover, Azerbaijan and Armenia are dragged into a conflict for the control over the Nagorno-Karabakh region. They also make different geopolitical choices and join conflicting foreign groupings. For example, Armenia is a CSTO member, and a pivotal state for Russian influence in the region, while Georgia is pro-Western oriented, seeking to join NATO and the EU; Azerbaijan closer cooperates with Turkey, and balances in its relations with Russia and Western countries. Any security interplay notably affects other regional states. Hence, in terms of security studies, the South Caucasus can be studied as a distinct regional security complex.

Based on Barry Buzan and Ole Wæver's RSC theory and research of Azerbaijani scholar Azad Garibov the paper aims to examine the security dynamics in the South Caucasus with a focus on Azerbaijan to study how domestic security is interconnected and linked to region 's neighborhood and global arena.

The research addresses three questions. First, considering the existing issues, what is the current security environment in the South Caucasus, and what are the specific national security challenges for Azerbaijan? Second, what is the policy of regional actors towards the South Caucasus? Third, what are the interests and patterns of influence of global players?

The period studied is from the dissolution of the Soviet Union and gaining of independence by the states of the South Caucasus in 1991, when the regional security complex was established.

The outline of the article is as follows. The first section studies domestically generated vulnerabilities and interstate relations in the South Cauca- 
sus, focusing on the main regional threats posed to Azerbaijan. The second section examines security interplay between the South Caucasus and its neighbors - Turkey, Iran, and Russia. In the fourth section, the role of global powers in the region - the US and the European Union are studied within the context of the security environment of the South Caucasus.

The regional security complex of the South Caucasus has been drawing the attention of the academic community for a long time, which has established a foundational background for the research. This research utilizes primary and secondary sources. The primary source used is the National Security Concept of the Republic Azerbaijan, as well as Caucasian and Western secondary sources such as academic articles, studying the development of the security complex of the South Caucasus, the main security threats to the region, and security issues of Azerbaijan.

The conceptual framework for the paper is the regional security complex theory (RSCT), elaborated by Barry Buzan and Ole Wæver. Authors state that "the central idea in RSCT is that, since most threats travel more easily over short distances than over long ones, security interdependence is normally patterned into regionally based clusters: security complexes (Buzan \& Wæver, 2003).

Hence, the RSCT analyzes domestically generated vulnerabilities (depending on the stability of the domestic order and correspondence between state and nation; state-to-state relations (producing the region itself); the region's interaction with neighboring regions; the role of global powers in the region (the interplay between the global and regional security structures) (Buzan \& Wæver, 2003).

\section{DOMESTIC LEVEL}

Most of the security dynamics operate at the regional level. Thus, there is a need to study inter-state relations between Armenia, Azerbaijan, and Georgia, constituting the South Caucasus. The regional dynamics is complicated by internal issues such as secessionist conflicts in Georgia and the Nagorno-Karabakh conflict between Armenia and Azerbaijan (Buzan \& Wæver, 2003). 
Leading Swedish scholar Svante. E. Cornell in his monograph "A study of Ethnopolitical Conflict in the Caucasus" states that "the complicated character of the relations between these three states, and the lack of any history of voluntary cooperation between them, must be defined as a main destabilizing factor. It is a fact that two states in the region, Azerbaijan and Georgia, see the third, Armenia, as a chief security threat to themselves and the entire region" (Cornell, 2005).

The Soviet past has powerfully influenced affairs in the region, and has resulted in the weak development of democratic institutions and political culture, along with authoritarianism, and ethnopolitical conflicts. These have caused the development of "competitive authoritarianism" and other types of "hybrid regimes", which combine authoritarian tendencies with the democratic elements to avoid challenging of incumbent authorities, creating instability in Caucasian states (Pataraia, 2015).

The pace of post-soviet transformation has been hampered by unresolved or so-called „frozen” conflicts, simultaneously influencing complex security situation. Democratization process, social-economic development, security, and defense area reforms, regional cooperation has been obstructed (Alieva, 2006).

Security and survival were among the primary challenges of statehood for the independent states of the South Caucasus. The most important security threat for the regional countries is the armed conflicts - two frozen separatist conflicts (in Georgia), and two interstate wars (between Armenia and Azerbaijan, Russia and Georgia). None of the three enjoys highly developed strategic cooperation with both of the other two countries. While Azerbaijan has a strategic partnership with Georgia, it is locked in a protracted conflict with Armenia. Despite Georgia's formal cooperation with Armenia, relations suffer from Armenia's function as a Russian "pivot" and military base, and the strong separatist ideas in the Armenian populated Javakheti region of Georgia (Garibov, 2017).

Azerbaijani scholar Azad Garibov declares the Nagorno-Karabakh conflict as the most serious security threat for the region. NagornoKarabakh is an enclave within Azerbaijan predominantly populated 
by Armenians. The conflict began at the end of the 1980s, when Armenia sought to annex the Nagorno-Karabakh Autonomous Oblast of Azerbaijan (NKAO), moving to fill the power vacuum created by the collapse of the Soviet Union. The conflict gradually evolved into a full-scale war between Armenia and Azerbaijan once they gained independence, leaving approximately 30,000 dead and over a million IDPs and refugees (Garibov, 2017). Thus, this is an interstate war, where one regional country - Armenia occupied Nagorno-Karabakh and seven adjacent districts (about 20\% of Azerbaijan's internationally recognized territories) (Garibov, 2017).

In 1994 with the mediation of Russia and Kyrgyzstan a cease-fire agreement was reached, which left the Karabakh Armenians under control of the local authorities and Armenia with control of $20 \%$ of Azerbaijan including access to it. There are international efforts undertaken to resolve the conflict by the OSCE "Minsk group", cochaired by France, the Russian Federation, and the United States (Buzan \& Wæver, 2003).

Azad Garibov claims that the conflict is not frozen, although international experts have described it as such, and it is closer to a "no war, no peace" situation. For example, the increased clashes since April 2016, known as the "Four-Day War", demonstrated that the conflict can flare up at any time, and destabilize the region (Garibov, 2017).

Consequently, the Nagorno-Karabakh conflict represents the key security threat for Azerbaijan. The National Security Concept of the Republic Azerbaijan highlights the "restoration its territorial integrity" as a key objective, and seeks "withdrawal of the armed forces of Armenia from all the occupied territories of the Republic of Azerbaijan" and "restoration of the sovereign rights of the Republic of Azerbaijan in these territories" (National Security Concept of the Republic of Azerbaijan, 2007). Azerbaijan officially declares the use of all means of international law for resolving the issue (National Security Concept of the Republic of Azerbaijan, 2007). Thus, the state opts for diplomatic means.

Due to spoiled relations with Armenia, Azerbaijan tries to isolate it as much as possible from regional economic projects. Hence, Arme- 
nia was excluded from such economic projects as the Baku-Tbilisi-Ceyhan (BTC), the Baku-Tbilisi-Erzurum, and the Baku-Tbilisi-Kars railway which brought changes to the economic conditions of the region (Garibov, 2017).

At the same time, Armenian foreign and security policy has been also formed under the influence of the Nagorno-Karabakh conflict. Armenia sought military and economic support and allied Russia, which has led to the country`s dependence on it (Garibov, 2017).

While Georgia, which was put in a difficult position by the ArmenianAzerbaijani conflict, has developed better relations with Azerbaijan than Armenia. There are several reasons for that, Baku is the economic center of the Caucasus, due to its oil resources and geographical position on the Caspian shore, Azerbaijan holds a central position in the different energy, transport and economic projects. Georgia, for its turn, is a transit country, linking Azerbaijan, Turkey, and the West (Garibov, 2017).

Political scientist Anthony R. Branch writes about Azerbaijan`s geopolitical advantage, and creating an unfavorable position for Armenia, exacerbating the state of relations in the South Caucasus. The author explains that "First, Armenia loses influence in Georgian-Armenian relations as Georgia will find Azerbaijan a much more profitable and beneficial partner [...] Second, the three of Armenia's four neighbors all become richer from these energy partnerships, thus increasing the financial disparity between Armenia and its neighbors. Third, Azerbaijan makes substantial gains with European countries as a necessary alternative for energy, especially as Western and Russian relations continue to worsen, thus giving more hard value to Azerbaijan over Armenia" (Branch, 2018).

Georgian scholar George Tarkhan-Mouravi also sees risks for regional stability in the growing inequality in military funding and hardware available to the three countries. He underlines that "Azerbaijan, with a population bigger than the combined populations of the other two SC countries, has by far the biggest defense budget, exceeding the total budget of its main regional adversary and challenger, Armenia, which compensates by far lower-priced purchasing armaments from Russia" (Tarkhan-Mouravi, 2016). 
Besides that, the dependence of Azerbaijan on its oil and gas can be seen as one of the main internal threats. In case of volatility at the global energy markets, the upcoming economic crisis can cause political instability and hit the Aliyev regime. (Branch, 2018).

Hence, the difficulties of post-Communist transitions of Armenia, Georgia, and Azerbaijan have negatively affected the regional security complex. The current security situation can be characterized as unstable. Secessionist regions within Azerbaijan and Georgia and their struggle for independence have affected the complex significantly. The relationship between Armenia and Azerbaijan are a zero-sum game, dragging resources from each of the party to a conflict. The risk of renewed clashes between conflicting parties undermines regional stability, impedes regional cooperation, and takes extra resources to ensure the security of energy infrastructure, carrying Caspian resources westwards.

\section{THE SOUTH CAUCASUS AND ITS NEIGHBORHOOD}

The important role in the security dynamics is played by the relations between the regional countries and their neighbors, in particular Russia, Turkey, and Iran. Each of the neighboring countries pursues its interests and patterns of influence in the South Caucasus.

Azad Garibov describes the region`s relations with its immediate neighbors as problematic (Garibov, 2017). Diplomatic relations between Russia and Georgia were suspended due to claims that its territorial integrity was violated by Russia. Armenia, in its turn, does not have diplomatic relations with Turkey, accusing Turkey of so-called "genocide" against Armenians. Turkey closed its borders with Armenia in 1993 due to Armenia's occupation of Nagorno-Karabakh and adjacent 20\% of Azerbaijani territory. Only Azerbaijan, despite experiencing some difficulties in relations with Iran, cooperates with all neighboring power (Garibov, 2017).

As it was mentioned above, Turkey like other neighboring countries, seeks to become a regional power and projects its influence on the South Caucasus. Shared ethnic, cultural, and linguistic affinity between Turkey and Azerbaijan laid a basis for the strategic partnership, implementation 
of trans-regional economic projects, and the coincidence of positions on the settlement of the Nagorno-Karabakh conflict. (National Security Concept of the Republic of Azerbaijan, 2007). As Turkey aims to become an international energy hub, cooperation with the South Caucasus a gateway to the Caspian region's oil and gas reserves, is important to it. Finally, the Armenian international campaign to achieve the recognition of the so-called "Armenian genocide" resulted in Turkey's alliance with Georgia and Azerbaijan (Garibov, 2017).

As it is stated in the National security concept of Azerbaijan "a trilateral strategic partnership and deepening cooperation between Azerbaijan, Georgia and Turkey has developed into a factor of stability in the region" (National Security Concept of the Republic of Azerbaijan, 2007). Georgia and Turkey are the transit countries of the Baku-Tbilisi-Ceyhan (BTC) and the Baku-Supsa oil export pipelines as well as the South Caucasus and Trans-Anatolian (TANAP) natural gas pipelines, and the Baku-TbilisiKars railway - the frontrunners of Azerbaijan's energy and transportation strategy, generating export revenues for Azerbaijan. Participation in these projects for Georgia is profitable due to the transportation fees it takes. Furthermore, Azerbaijan and Turkey support Georgian sovereignty and security, as any threat to Georgia will have implications for Azerbaijan and Turkey (Garibov, 2017).

The Georgian-Russian war of August 2008 raised Turkey's security concerns and within the foreign policy of the "zero problems with neighbors", Turkey initiated the establishment of a "Caucasus Stability and Cooperation Platform”, including Turkey, Russia, Azerbaijan, Georgia and Armenia. However, this idea did not come to life due to the opposite positions of its potential members.

Iran which is another important neighbor of the South Caucasus due to its geographical position and political leverage. It has sought to develop its relations with regional countries after the collapse of the Soviet Union and used to position itself within a Moscow axis. Recently, Iran has adopted a more comprehensive stance (Gafarlı et al., 2016).

Relations between Iran and Azerbaijan are rather complicated since Iran sees in the large Azerbaijani population in the northwestern part of the country (about 25 million people) a threat to its national security. 
Meanwhile, Iran stands on the pro-Armenian position in the NagornoKarabakh conflict and cooperates in the economic and energy field. Other issues are Azerbaijan's cooperation with the West in the "War on Terror" and with Israel in military matters, as well as western-oriented energy projects. In addition, there is a divisive issue of the Caspian, which is significant for energy resources and has an impact on bilateral relations with a potential for confrontation (Gafarlı et al., 2016).

After considering the inter-play between Iran, Turkey and the South Caucasus special attention should be paid to the policy of the Russian Federation. Russia perceives the South Caucasus as a part of its sphere of influence in the multipolar world - the so-called "near abroad". Having geopolitical, security, and economic interests in the region Russia owes a wide range of leverages to apply to reach its goals. It plays a particular role in regional conflicts and builds alliances with Armenia, hosting the Russian military base in its territory, as well as with Iran to block Western and Turkish political and economic initiatives in the region.

Armenian political scientist Richard Giragosian states that during the 1990s regional states heavily relied on Russia for trade, transport, and energy, and these vulnerabilities were deepened by ethnic conflicts and border disputes (Giragosian, 2007).

Azerbaijani scholar Araz Aslanlı defines following goals of Russia in the region: "to achieve a shorter path southwards (to the Indian Ocean, as a part of its expansionist strategy) and to strengthen its aspirations to become a global power by keeping the region under control; to keep Turkey and Iran and other states away from its borders; to limit/ terminate the separatist attempts of different ethnic groups in its southern regions of Russia (the North Caucasus), thus reducing concerns about territorial integrity; to prevent (or at least limit) the transportation of natural resources into the world market or to limit this process, thereby maintaining its market dominance; to prevent the new states from strengthening their independence and ensure that they remain dependent on Russia to the greatest extent possible, etc" (Aslanl, 2017).

Political scholar Leila Alieva argues that under Vladimir Putin's presidency, Russia supports the secessionist movements, thus weakening the neighboring states, and uses their energy dependence, including gas prices, 
a large number of guest workers and common borders as means of political pressure (Alieva, 2006). For instance, during the conflict between Georgia and Russia in 2008 Russian gas exports were cut after Tbilisi rejected a dramatic increase in price in 2007 (Garibov, 2017).

To regain its positions in the international arena and prevent its socalled "Western encirclement" Russia engaged in the war with Georgia in August 2008. The conflict has made the region more volatile than before. Along with Armenia, Azerbaijan faced serious challenges during the war between Russia and Georgia. The Russian Federation acknowledge the proclamation of independence of two Georgian secessionist regions South Ossetia and Abkhazia, and established its military bases there (Gafarlı et al., 2016).

Among the three countries, Armenia maintained the closest relations with Russia. Hence, Armenia is pushed to participate in all Russia-led post-Soviet integration projects (CIS, CSTO, EAEC, SES, Eurasian Customs Union, EAEU). The Armenian dependence on Russia was determined by its lack of choice due to its limited natural resources, landlocked geopolitical position, closed borders, and conflicts with Azerbaijan and Turkey (Gafarl et al., 2016).

In its turn, unlike Georgia which has consistently pursued its goal of joining NATO and closely cooperates with it, Azerbaijan is trying to maintain balanced policy by closely cooperating with NATO member Turkey, developing economic and energy projects with its Western partners, and, at the same time, avoids any kind confrontation with Russia.

To escape membership in military blocs, entailing dependence and limitations on sovereignty, Azerbaijan joined the Non-aligned Movement in 2011. Azerbaijani scholar Dr. Javid Valiyev argues that it which assisted Azerbaijan in the following respects: "1) avoiding the pressures of regional organizations in the geopolitical struggle in the South Caucasus, and maintaining a balanced foreign policy; 2) putting an end to the rumors about possibilities of Azerbaijani membership in either NATO or the CSTO" (Valiyev, 2017).

Thus, according to RSC theory, there is a polarized dynamics, in which regional and external states are involved. Turkey supports Azerbaijan and Georgia, while Russia and Iran support Armenia and secessionist regions 
of Georgia. There is no doubt that among the neighboring countries Russia shapes the region most, as Russian trace can be seen in secessionists conflicts in Georgia, the conflict over Nagorno-Karabakh between Azerbaijan and Armenia, and competition for the control over energy resources transit. Azerbaijan is the only country of the South Caucasus which managed to limit Russian influence and avoid geopolitical alignment distinctive to regional states.

\section{GLOBAL LEVEL}

Due to its geographical position, the South Caucasus attracts the attention of the world-leading powers - the US and the EU. The involvement in the regional complex of these actors is unavoidable since the region is as a buffer zone lying between Russia, Turkey, and Iran. There is a need for the United States and the European Union to project their influence and engage in this extremely volatile region.

The US has had a few foreign policy strategies in this region. The involvement in regional affairs has been important to advance their interests in the energy projects of the Caspian basin and limit the influence of Iran and Russia. Turkish experts highlight that "with a growing rift between Russia on the one hand and the US and the EU on the other regarding Ukraine and Syria, and an escalating conflict in NagornoKarabakh that might draw in regional powers, the South Caucasus may well become the third spot for employing the strategy of encircling Russia" (Gafarli et al., 2016).

For a long period during the 1990s, the US policy towards the South Caucasus was a part of a wider policy to the post-soviet space aimed at promoting the US economic interests and supporting democracy, so relations between the world leader and Caucasian states were viewed through the prism of Russian-American relations. However, the activity of the Armenian lobby and energy investors pushed American political establishment to develop a separate strategy towards the region.

In 1997 due to socioeconomic and financial problems faced by Russia the Clinton administration took a decisive step to access the energy 
resources of the Caspian basin. Hence, the US engaged in the South Caucasus (Gafarli et al., 2016). Azerbaijan with its vast energy resources became an alternative to Iranian and Russian energy supplies, and Georgia with its geographical position and stable relations with neighboring countries became a hub for regional projects and started to threaten Russia with its Western integration aspirations, namely with NATO (Gafarlı et al., 2016).

After the terrorist attacks of 9/11 and the following "Global War on Terror" the South Caucasus served as a launching pad for the US military forces on the way to Afghanistan and Iraq, leading to the intensification of relations between the region and NATO (Gafarlı et al., 2016).

The "Rose Revolution" and change of political elite in Georgia was welcomed and supported by the US and turned Georgia into the main American ally in the region. The changes came with the Obama administration which initiated "reset policy" with Russia in 2009, since this event the policy of the US towards the region has changed (Garibov, 2017). Besides, The Obama administration put the main emphasis on the issue of democracy and civil society, which caused the dissatisfaction of Azerbaijan`s party (Gafarlı et al., 2016). With the new Trump administration, American involvement in the region remains low.

The following leading international actor, engaged in the South Caucasus is the EU. During the 1990s, the EU perceived the region as a periphery with a huge number of problems, and was more concentrated on the issues of its development. The situation changed when the EU became interested in the regional energy resources and construction of the transportation corridor between East and West, North and South. Thus, the EU signed the Partnership and Cooperation Agreements with Armenia, Georgia, and Azerbaijan in 1996 (Shahbazov, 2017).

Over the years three states became a part of the EU's European Neighborhood Policy (ENP) and the Eastern Partnership (EaP). The first one is aimed at the democratization of the EU's southern and eastern neighbors via economic integration and cooperation with various EU institutions, including non-governmental organizations (Shahbazov, 2017). Although the ENP project allowed the regional countries to collaborate with the EU in different fields, it did not bring tentative results. 
Hence, the EU initiated the Eastern Partnership program (EaP) in 2009, supporting stability by contributing to the conflict resolution, the creation of free trade zones, and provision of financial support, visa liberalization, educational programs, etc. One of the main goals of the $\mathrm{EaP}$ is to facilitate institutional reforms through the adoption of EU regulations (Shahbazov, 2017). Thus, the EU seeks to provide security to itself first of all by ensuring stability at its borders, namely the South Caucasus.

Political expert Fuad Shahbazov states that "Azerbaijan is a critical partner in the South Caucasus due to its natural resource wealth, and the fact that it has the largest population potential in the region. The EU Azerbaijan partnership is mainly based on the support to a peaceful settlement of the Armenia-Azerbaijan Nagorno-Karabakh conflict, empowerment of democratic institutions, and support of balanced economic development" (Shahbazov, 2017).

Cooperation in the energy field is a top priority of the partnership between the EU and Azerbaijan. Azerbaijani natural resources are important for the improvement of the European energy security and reducing dependency on Russian gas, associated with the Russian use of energy supplies as a tool for political pressure. The EU is seeking to integrate Azerbaijan (and other South Caucasus republics) into a pan-European energy market to liberalize and modernize its energy sector (Pataraia, 2015).

Within this policy, the European Commission proposed the Southern Gas Corridor in 2008, intended to transfer natural gas from Azerbaijan to Europe via the South Caucasus Pipeline (SCP) (Shahbazov, 2017). However, The SGC follows a route close to several regional conflicts, namely running close to Nagorno-Karabakh and South Ossetia. Clashes between Azerbaijan and Armenia over Nagorno-Karabakh carry a lot of risk, as the Armenian military may attack energy infrastructure. Also, Russia may become involved in a conflict as Armenia's ally within the Collective Security Treaty Organization. Furthermore, Russian troops are stationed in South Ossetia at its military base, so it is easy for them to access the SGC infrastructure in Georgia, as it was during the August 2008 war (Siddi, 2019).

Despite cooperation in the fields of economy and energy Azerbaijan in its relations with the EU avoids taking serious political obligations. Within 
its balanced foreign policy course country seeks to secure itself in a complicated geopolitical environment of the South Caucasus, where Russia pursues aggressive police.

There are expectations for political support from the EU in realizing the mutually beneficial SGC project and resolving the Nagorno-Karabakh conflict (Shahbazov, 2017). Azerbaijani party is dissatisfied with the EU's position on the unresolved Nagorno-Karabakh conflict. Azerbaijan has pursued a campaign for the recognition of the illegal occupation of the Nagorno-Karabakh region by Armenia for years. However, the EU failed to recognize Azerbaijan's territorial integrity in the same way it has done concerning territorial disputes in Moldova, Georgia, and Ukraine (Shahbazov, 2017). Although, the European Union supports the work of the OSCE Minsk Group Co-Chairs and periodically mentions that the status quo is insufficient (Gafarlı et al., 2016).

Consequently, after the end of the Cold war and dissolution of the Soviet Union, the EU and the USA have involved in the South Caucasus by establishing various cooperation mechanisms. Issues of security, geopolitical competition, democratic development, energy resources, transit potential of the region have been on the agenda. The energy resources and their transit are main drivers to the global players' involvement in the region, namely the development of the South Caucasian energy transit corridor occupies a significant place within the European Union's energy security system. The significant factor of regional security is its vulnerability to Russian pressure, with energy as an essential leverage. While the U.S. pursues energy security as part of a broader strategy of diversification of resources and suppliers, the European Union faces a need to overcome its growing structural dependence on Russian energy supplies as well as a need to ensure security on its borders. However, the EU`s cooperation with the South Caucasus has produced limited results. Whilst the US involvement has significantly decreased especially during the Donald Trump administration. 


\section{CONCLUSIONS}

This paper is an analysis of the dynamics within the regional security complex of the South Caucasus. After considering domestic vulnerabilities, and the interplay between regional and global actors and its implications for the countries of the South Caucasus, namely Azerbaijan, one can draw the following conclusions.

The South Caucasus is a conflict-riven region, experiencing inter-state and secessionist conflicts. Despite internal vulnerabilities caused by the post-communist transition, the relations between states are hostile as well as with their neighbors. Armenia hosts a Russian military base on its territory and has no diplomatic relations with Azerbaijan and Turkey. It is completely isolated from all regional economic projects, due to its position on the Nagorno-Karabakh conflict and occupation of 20\% of Azerbaijani territory. At the same time, Azerbaijan cooperates with neighboring and global powers, and partners with Georgia. The unresolved dispute over Nagorno-Karabakh is the key impediment to regional cooperation. Unlike, Armenia and Georgia, which is committed to its NATO and EU aspirations, Azerbaijan does not seek national security guarantees of regional or global players, so it became a member of the Non-Aligned Movement in 2011. One of the core interests of Azerbaijan is to ensure the security of energy transportation, due to its reliance on energy revenues, providing necessary resources for stability, which is extremely hard to reach in the security environment of the South Caucasus.

The region of the South Caucasus has turned to an arena for competing regional and global players. Russia, Turkey, and Iran continue to project their interests and influence on it. At the same time, the policy of the global players - the EU and the USA is dominated by the issues of the Caspian Sea energy reserves and their export routes. At present, Russia seeks to control "near abroad" to regain its position as a global player. It is involved in the regional conflicts, and successfully keeps the three countries from joining NATO or the EU. Armenia is the only South Caucasus member of CSTO and the EAEU and is extremely dependent on Russia in the economic and energy field. Azerbaijan is not that exposed to Russian influence, as the other two states, but it has to consider Russian policy, especially 
within the context of Nagorno-Karabakh conflict and energy transit. Military bases in Abkhazia and South Ossetia provide Russia with both a key leverage against Georgia and a structural advantage for potential Russian military operations in the region, impeding Georgia 's membership in NATO and the EU. Both Iran and Turkey do not possess enough resources and political tools to overcome Russian domination over the South Caucasus. Iran has an impetus to improve its economic relations with all of the South Caucasus states, but it has met some constraints on the way to this goal. Turkey closely cooperates with Georgia and Azerbaijan, pursuing its aim to become an energy hub.

The global players - the US and the EU for a long time were perceived as the major challenges to Russia in the Caucasus. However, they currently play rather peripheral roles in the region. The EU is more concerned with the issue of energy diversification and security on its border, without taking deceives steps in the conflict resolution processes. At the same time, the US since the Obama administration has considered the South Caucasus through the prism of their relations with Russia, and the Trump administration's agenda has become even more US-focused, so there is even less US interested in the region.

Thus, taking the existing security environment into account, it is necessary to resolve issues that are vital for the stability of the South Caucasus. There is an urgent need to strengthen democratic governance and pursue democratic reforms in general as well as to find a solution to regional conflicts, which is hard to reach without support from the global leaders - the EU and the US. The elimination of internal threats, will decrease Russian influence on the region and will bring the stability, as well as secure the energy infrastructure.

\section{BIBLIOGRAPHY:}

Alieva, L. (2006). EU and South Caucasus. The Center for Applied Policy Research. Downloaded from: http://www.cap.lmu.de/download/2006/2006_Alieva.pdf Aslanlı, A. (2017). Caucasus in the Global Struggle in the Last 25 Years. Baku: Caucasus International. 
Branch, A. R. (2018). Armenia and the South Caucasus: A New Security Environment. Downloaded from: http://connections-qj.org/system/files/17.2.04_branch_armenia. pdf

Buzan, B. \& Wæver, O. (2003). Regions and Powers. The Structure of International Security. New York: Cambridge University Press.

Cornell, S. E. (2005). Small Nations and Great Powers: A Study of Ethnopolitical Conflict in the Caucasus. London: Routledge.

Gafarl, O., Anapiosyan, A. et al. (2016). The Role of Global and Regional Actors in the Sout Caucasus. Downloaded from: https://caucasusedition.net/wp-content/ uploads/2016/06/Actors-ENG.pdf

Garibov, A. (2017). Security Dynamics in the South Caucasus since Independence: Interconnected Threats and Security Interdependence. Baku: Caucasus International. Giragosian, R. (2007). Shifting Security in the South Caucasus. Downloaded from: http:// connections-qj.org/system/files/06.3.06_giragosian.pdf

National Security Concept of the Republic of Azerbaijan (2007). Downloaded from: https://www.files.ethz.ch/isn/154917/Azerbaijan2007.pdf

Pataraia, T. (2015). Energy Transit and Security Imbalance in South Caucasus: the Road between Russia and the European Union. Downloaded from: https://ge.boell.org/ sites/default/files/uploads/2015/03/energy_eng-final_1.pdf

Shahbazov, F. (2017). The EU and the South Caucasus 25 years since Independence: Azerbaijan in the Geopolitical Strategy of the EU. Baku: Caucasus International.

Siddi, M. (2019). The Southern Gas Corridor: Prospects and Challenges for EU Foreign Policy. Downloaded from: https://css.ethz.ch/content/dam/ethz/special-interest/gess/ cis/center-for-securities-studies/pdfs/CAD112.pdf

Tarkhan-Mouravi, G. (2016). Old and new threats to security in the South Caucasus. Lublin: East of Europe.

Valiyev, J. (2017). Foreign Policy of Azerbaijan in 25 Years of Independence: Priorities, Principles, and Achievements. Baku: Caucasus International. 